УДК 378.091.212:316.77:82

DOI:

Тетяна Шарова, кандидат філологічних наук, завідувач кафедри української $і$ зарубіжної літератури Мелітопольського державного педагогічного університету імені Богдана Хмельницького Сергій Шаров, кандидат педагогічних наук, доиент кафедри інформатики і кібернетики Мелітопольського державного педагогічного університету імені Богдана Хмельницького

\title{
ФОРМУВАННЯ КОМУНІКАТИВНОЇ КОМПЕТЕНТНОСТІ МАЙБУТНІХ УЧИТЕЛІВ ІНФОРМАТИКИ ЗАСОБАМИ ТВОРЧИХ РОБІТ
}

У статті розглянуті можливості застосування творчих робіт для формування комунікативноі компетентності майбутніх учителів інформатики. Зазначається, щуо комунікативна компетентність є однією із важливих компонентів підготовки сучасного фахівия, входить до переліку фахових компетентностей викладача, дозволяє забезпечити ефективне спілкування між учасниками освітнього прочесу. Авторами аналізується визначення та структура комунікативної компетентності, обгрунтовується доцільність застосування творчих робіт для формування комунікативної компетентності майбутніх учителів інформатики, подаються методичні вказівки щзодо їх застосування у навчальному процесі.

Ключові слова: комунікативна компетентність; майбутній вчитель інформатики; вища школа; навчальний процес; творча робота.

Jim. 13.

Tetyana Sharova, Ph.D.(Philology), Head of the Ukrainian and Foreign Literature Department Melitopol Bohdan Khmelnytskiy State Pedagogical University

Serhiy Sharov, Ph.D.(Pedagogy), Associate Professor of the

Informatics and Cybernetics Department

Melitopol Bohdan Khmelnytskiy State Pedagogical University

\section{FORMATION OF COMMUNICATIVE COMPETENCE OF FUTURE TEACHERS OF COMPUTER SCIENCES BY MEANS OF CREATIVE WORKS}

Modern requirements for the training of a competitive specialist actualize the necessity for updating the content of education, taking into account the competence approach. One of the important qualities of modern youth is the presence of the developed communicative competence, the ability to communicate effectively in order to achieve constructive results. This is especially true for teachers who must prepare young generation for a dynamic information environment.

The definition and the structure of communicative competence of teachers are analyzed, including teachers of computer sciences. It is noted that communicative competence is included into the list of the teacher's professional competences and assumes the ability to enter into communication, to be clear among the interlocutors during the performance of their professional duties. The teacher of computer sciences is a guide to the world of information technologies, which reveals to the students the laws and benefits of the information society. He must operate with terms, be aware of the current trends in the development of information and communication technologies and be able to communicate with students at a level that is clear to them.

The expediency of using the creative works forms the communicative competence of future informatics teachers of computer sciences. Their use in the preparation of future specialists will allow students to clearly express their own opinion on a particular issue, widen their horizons, increase their ability to communicate, and defend their own opinion during public protection. Each theme of creative work can be controversial, disclosed and protected in the different ways.

There are examples given on the theme of creative work that is appropriate to provide the future computer science teachers. Methodical advice is offered on registration and writing of the creative works during independent study and classroom work. It is noted that creative work effectively influences on the development of communicative competence of future teachers of computer sciences and it must undergo the public protection process among the other students of the group.

Keywords: communicative competence; a future teacher of computer sciences; high school; an educational process; creative work.

П остановка проблеми. Сучасне інформаційне суспільство актуалізує потребу у вихованні інформованих i компетентних особистостей, які здатні відповідати за свої вчинки, приймати самостійні рішення та бути фахівцями усвоїй справі. 3 огляду на це, важливим завданням сучасної освіти є формування особистості, яка володіє певним 
переліком професійних компетентностей та у процесі життєдіяльності поступово розкриває творчі, навчальні та особистісні можливості.

Необхідною якістю сучасного фахівця $\epsilon$ здатність до спілкування $з$ однодумцями та нефахівцями під час вирішення професійних, побутових, економічних питань тощо. Особливо це стосується викладачів та вчителів, зокрема вчителів інформатики, які повинні вільно спілкуватися $з$ учнями та донести до них сучасні тенденції розвитку суспільства, науки, інформаційних технологій тощо. Оскільки інформаційно-комунікаційні технології (IКТ) постійно розвиваються, вчитель інформатики повинен завжди бути обізнаний у цих змінах, повідомляти про них учням доступною мовою у процесі конструктивного діалогу. Саме тому формування комунікативної компетентності майбутніх вчителів інформатики є актуальним.

Аналіз останніх досліджень і публікацій. Визначенням структури та етапів формування комунікативної компетентності педагогів займалися Н. Ашиток, С. Філатова, К. Касярум та інші вчені. Ф. Єщенко, Н. Самборська досліджували значення комунікативної компетентності у структурі професійних компетентностей. Н. Дегтярьова 3 метою розвитку комунікативної компетентності майбутніх учителів інформатики застосовувала есе. Водночас, формування комунікативної компетентності майбутніх учителів інформатики через написання творчих робіт досліджено недостатньо.

Метою статті $\epsilon$ аналіз доцільності застосування творчих робот у процесі формування комунікативної компетентності майбутніх учителів інформатики.

Виклад основного матеріалу. У Національній стратегії розвитку освіти в Україні на період до 2021 року зазначається, що за останні роки зроблено низку заходів, спрямованих на підвищення якості та доступності освіти, підвищення її конкурентоспроможності. В той же час, $є$ певні проблеми, які потребують подальшого вирішення, а саме: недостатня відповідність освітніх послуг вимогам суспільства; зниження культури поведінки частини учнівської та студентської молоді; повільне здійснення інформатизації освіти тощо [10]. Це зумовлює подальшу роботу урядовців, викладачів, науковців над вирішенням проблем підвищення якості освіти та підготовки підростаючого покоління до активного життя.

Сьогодні активно відбуваються процеси, що стосуються змін у середній та вищій школі, зокрема оновлення змісту освіти з урахуванням компетентнісного та студентоцентрованого підходів до навчання. О. Овчарук наголошує на тому, що у сучасних освітніх реаліях, пов'язаних 3 інтеграцією до світового та європейського простору, відбувається створення навчальних програм, орієнтованих на набуття здобувачами освіти ключових компетентностей та розробка механізмів їх ефективного впровадження [8]. Саме тому формування та розвиток професійних компетентностей майбутніх фахівців є умовою їх успішного працевлаштування за обраною професією.

Як зазначає I. Кубенко, компетентнісною людина може стати тільки після отримання нею певного практичного досвіду, професійних знань та умінь, а також таких якостей, як здатність до співробітництва, ініціативність, вміння аналізувати інформацію, оцінювати ситуацію тощо [7, 1]. Слід зазначити, що якісне спілкування 3 друзями, однодумцями, колегами по роботі тощо неможливо без сформованої на достатньому рівні комунікативної компетентності, оскільки саме вона передбачає наявність здатності вступати в комунікацію, спілкуватись без обмежень та бути зрозумілим серед співрозмовників.

На нашу думку, комунікативна компетентність фахівця формується кожного дня, незалежно від обраного фаху чи профілю. Вона заснована на знаннях та життєвому досвіді особистості, що надає їй змогу орієнтуватися у конкретних ситуаціях під час спілкування та вирішувати виниклі проблемні питання. Комунікативна компетентність завжди набувається в соціальному контексті, оскільки обов'язково передбачає діалог між учасниками спілкування. О. Кривонос наголошує, що комунікаційна компетентність включає в себе знання необхідних умов, способів взаємодії з оточуючими, навички роботи в групі, володіння різноманітними соціальними ролями в колективі $[6,28]$.

Наразі сучасні інформаційні технології часто позбавляють людей від спілкування у колективні або “віч на віч”. Водночас, $є$ багато професій, які вимагають розвиненої здатності до комунікації, добре сформованої комунікативної компетентності. Це педагоги, організатори, управлінці різного профілю, психологи, менеджери та багато інших професій. Причому комунікативна компетентність педагога має специфічні особливості, які зумовлені віковими та психофізіологічними особливостями молоді.

Якщо розглядати професійні компетентності викладача, то, на думку В. Введенського, вони знаходяться у причинно-наслідковому зв'язку із 

ЗАСОБАМИТВОРЧИХ РОБІТ

особистісними якостями, педагогічною діяльністю та отриманими результатами. До їх складу дослідник відносить комунікативні, інформаційні, регулятивні, операційні та інтелектуальнопедагогічні компетентності [2, 22]. Всі вони пов'язані між собою та призначені для забезпечення якісного освітнього процесу.

Комунікативна компетентність педагога в цілому визначається як здатність спілкуватися 3 різними суб' єктами навчального процесу [3, 58]; встановлювати та підтримувати необхідні контакти $з$ іншими людьми; певну сукупність знань, умінь і навичок, що забезпечують ефективність спілкування $[11,104]$; здатність до ефективного спілкування під час виконання власних професійних обов'язків $[1,11]$. У цьому контексті Н. Самборська зазначає, що певні відмінності у визначені цієї дефініції пояснюються належністю дослідників до різних галузей знань, але вони не впливають на сутність проблеми в цілому [9, 129].

Викладач повинен зберігати психологічну рівновагу, розуміти співрозмовника, його потреби та почуття, підлаштовуватися під його психологічний стан під час спілкування з метою досягнення взаєморозуміння $[1,11]$. Водночас, ефективне спілкування завжди передбачає творчий процес, сприяє розвитку особистості, робить їі більш комунікативною та успішною. Крім того, воно опосередковано впливає на подальше успішне працевлаштування та виконання професійних обов' язків.

До структури комунікативної компетентності можна віднести лінгвістичну, мовленнєвута мовну компетентності. Тут не слід забувати про формування різноманітних якостей та умінь людей, що опановують зазначеною компетентністю: стиль мовлення, імідж вчителя, звукове оформлення, практичне спрямування, змістове наповнення. В цьому контексті важлива обізнаність вчителя щодо актуальних питань науки, суспільства, навчального предмету, яка допоможе йому краще підготувати молодь до самостійного життя в соціумі $[13,75]$.

Більшість завдань, пов'язаних із взаємодією та спілкуванням $з$ учнями, передбачає наявність у вчителя добре сформованої комунікативної компетентності, яка має певні складові. У першу чергу, це комунікабельність, яка передбачає здатність контактувати з різними людьми. Не менш важливо володіти змістовою інформацією та правильно іï подавати. Також у пріоритеті $\epsilon$ здатність до досягнення взаєморозуміння. У цьому аспекті важлива гнучкість під час спілкування, яка дозволяє змінювати хід розмови в залежності від психологічного стану співрозмовників.

В умовах впровадження та використання мобільних пристроїв, Інтернет, соціальних мереж та дистанційної освіти вчитель інформатики є тією людиною, яка зможе показати учням переваги використання інформаційно-комунікаційних технологій під час виконання навчальної діяльності, у спілкуванні, побуті. Він повинен оперувати масивом інформатичних термінів, бути обізнаний у сучасних тенденціях розвитку інформаційно-комунікаційних технологій, знати напрямки їх використання хоча б на базовому рівні.

Учитель інформатики повинен так побудувати заняття, щоб учні змогли застосувати отримані знання на практиці, розвинути соціальні та комунікативні компетентності, поступово дізнаватися про мінливий світ в інформаційному просторі. Звісно, щоб цього досягти, учитель повинен бути оратором, володіти гарною дикцією та вміти знаходити з учнями спільну мову для подальшої комунікативної взаємодії.

Дослідниця К. Касярум акцентує увагу на тому, що комунікативна компетенція викладача вищого навчального закладу пов'язана 3 інформаційною компетентністю, здатністю використовувати мультимедіа та Інтернеттехнології, вміннями створювати навчальну документацію, планувати процес комунікації та прогнозувати iï результати, здатністю до комунікації під час навчальної, дослідницької, пізнавальної та інших видів діяльності $[5,26]$. В цьому аспекті доречна думка Ю. Сщенко, який вважає, що педагог повинен у процесі спілкування зі студентами, учнями, адміністрацією донести до них власну думку, зробити іiі зрозумілою, спонукати до подальшої діяльності [4].

Одним із засобів формування комунікативної компетентності майбутнього вчителя інформатики ми вбачаємо у використанні творчих робіт. Вони дозволять не тільки розвинути уміння зрозуміло та творчо відтворювати власні думки та знання у вигляді тексту, а також сформувати комунікативні здібності та здатність відстоювати власну думку під час захисту роботи перед одногрупниками. За допомогою творчої роботи можна розвинути навички логічного мислення, представлення проблеми у зручному вигляді, навчити формулювати власні висновки. Крім того, написання творчих робіт дозволяє розширити кругозір студента/учня, який їх пише.

Творчу роботу можна представити як твір, утворений поєднанням інтуїтивного та дискурсивного під час самостійного вираження 
своїх думок на конкретну тему. За своїм змістом творчі роботи можуть бути різного типу:

- вільні теми (у своїй основі передбачають роздуми різного змістового наповнення);

- напіввільні теми (вміщують в себе певний базис, який відомий усім);

- твори літературознавчого змісту (переважно це характеристика головних персонажів або подій, про які розповідається у творі);

- творчі роботи креативного характеру (як правило, різні за жанром твори, написані автором на основі власних думок) $[12,19]$.

За своєю суттю написання творчої роботи $\epsilon$ діалектичним процесом, що має відповідні етапи та механізми. Кожна тема може бути дискусійною та розкриватися по-різному. Досить часто творчі роботи передбачають глибоке вивчення окремих питань курсу, розвиток у здобувачів освіти креативності та практичних навичок письмового мовлення.

Роботи такого типу можна давати безпосередньо на занятті або у вигляді завдань для самостійного опрацювання. Однак, слід орієнтуватися на засвоєння студентом навчального матеріалу, оскільки для відтворення певної теми йому потрібно ознайомитися із поняттями, якими можна оперувати під час виконання завдання. Тому творчу роботу доцільніше впроваджувати наприкінці вивченої теми, коли майбутній учитель вільно орієнтується у тематиці, може провести паралелі між темами та навести приклади. Після виконання творчого завдання його рекомендується обговорити в аудиторії 3 метою доказу власної думки, підвищення комунікативної компетентності, повторення навчального матеріалу.

Для формування комунікативних компетентностей майбутніх учителів інформатики, які міркують точними термінами та часто використовують цифри, можна запропонувати написання творчих робіт за такими темами: “Цифровий імідж вчителя інформатики”, “Інформаційне суспільство та педагогічна освіта”, “Інновації в освіті”, “Значення медіа грамотності у розвитку підростаючого покоління", “Перспективи розвитку штучного інтелекту” тощо. Власне, тематика залежить від навчальної дисципліни, на якій вони будуть впроваджуватися. Слід наголосити на тому, що не треба давати велику кількість тем для творчої діяльності. Крім того, теми творчих робіт повинні бути зрозумілі і не занадто вузькі, оскільки студент повинен проявити свою креативність та здатність до міркувань $[12,21]$. Якщо викладач не ставить перед собою мету контролю, а просто передбачає розвиток комунікативної компетентності, то можна не обмежувати студента у виборі теми.

Починаючи писати творчу роботу, слід обрати форму ii представлення. Крім того, під час написання потрібно дотримуватися основних правил, які висуваються до робіт такого типу. Треба не лише розкрити заявлену у роботі тему, а й скористатися певними твердженнями під час захисту для обговорення власної позиції. Творча робота обов'язково повинна містити вступну та основну частини, висновки. Її обсяг повністю залежить від стилю та жанру твору, безпосередньо задуму та способу розкриття теми.

Після того, як творча робота написана, ㄲï потрібно публічно захистити перед іншими студентами. Це можна зробити під час наступного лекційного заняття, використовуючи комбінований тип подання навчального матеріалу. Під час обговорення творчу роботу можна зачитати, або по ходу читання робити певні коментарі та розширити представлену тему.

Висновки. Отже, комунікативна компетентність $\epsilon$ важливою складовою становлення активної та конкурентоспроможної особистості, яка здатна спілкуватися та досягати порозуміння. Природне формування комунікативної компетентності не відповідає вимогам сучасної дійсності, оскільки воно занадто повільне. Саме тому для і1і формування слід використовувати різноманітні засоби, які дозволять посилити мовленнєву та творчу складову фахової підготовки, покращити якість спілкування. Формування комунікативної компетентності майбутніх учителів інформатики засобами творчих робіт розвиває нові можливості особистісного зростання здобувачів вищої освіти та спонукає до використання набутих знань у подальшій професійній діяльності.

\section{ЛІТЕРАТУРА}

1. Ашиток Л. Комунікативна компетентність педагога: структура, етапи формування / Л. Ашиток // Молодь і ринок. - 2015. - №6(125). - С. $10-13$.

2. Введенский В.Н. Компетентность педагога как важное условие успешности его профессиональной деятельности / В.Н. Введенский // Инновации в образовании. - 2003. - №4. - С. 21 $-31$.

3. Дегтярьова Н.В. Застосування есе з метою розвитку комунікативної компетентності майбутніх учителів інформатики / Н.В. Дегтярьова // Фізикоматематична освіта. - 2017. - Вип. 2(12). - С. 57 -60 .

4. Сщенко Ю.Ф. Комунікативна компетентність як складова професійної компетентності викладача 
вищого навчального закладу / Ю.Ф. Єщенко // Вісник національної академії Державної прикордонної служби України. - 2010. - Вип. 2. Режим доступу: http://nbuv.gov.ua/UJRN/ Vnadps_2010_2_11.

5. Касярум К.В. Комунікативна компетентність викладача вищої школи / К.В. Касярум // Наукова скарбниця освіти Донеччини. - №2(15). - 2013. C. $24-27$.

6. Кривонос О.М. Формування інформаційнокомунікаційних компетентностей майбутніх учителів інформатики в процесі навчання програмування: дис. ... канд. пед. наук: 13.00.02 / О. М. Кривонос. - К., 2013. - 284 с.

7. Кубенко I. М. Що таке компетентність і як iii розуміють в освіті: [Електронний ресурс] / I. М. Кубенко // Додаток до електронного журналу “Теорія та методика управління освітою”. - Вип. 1. - 2010. - 13 с. - Режим доступу: http://www.tme.umo.edu.ua/docs/Dod/ 1_2010/kubenko.pdf.

8. Оварчук О. Компетентності, як ключ до оновлення змісту освіти: [Електронний ресурс] // O. Овчарук. - Режим доступу: http://osvita.ua/ school/method $/ 381 /$.

9. Самборська Н. М. Комунікативна компетентність уструктурі професійної компетентності майбутнього фахівця / Н. М. Самборська // Вісник Житомирського державного університету імені Івана Франка. Педагогічні науки. - 2016. - Вип. 1. - С. $126-130$.

10. Указ Президента України Про Національну стратегію розвитку освіти в Україні на період до 2021 року від 25 червня 2013 року № 344/2013: [Електронний ресурс]. - Режим доступу: http:// zakon3.rada.gov.ua/laws/show/344/2013.

11. Черезова I.О. Комунікативна компетентність як інтегральна якість особистості / I.О. Черезова / / Науковий вісник Херсонського державного університету. - Вип. 1. - Т.1. - 2014. - С. 103 107.

12. Шарова Т.М. Історія української літератури I пол. XIX ст. / Т.М. Шарова. - Х.: Майдан, 2017. $-272 \mathrm{c}$.

13. Шарова Т.М. Формування комунікативнодіалогічної компетентності студентів-філологів / Т.М. Шарова, С.В. Шаров, О.В. Бородихіна // Науковий Вісник міжнародного гуманітарного університету. Сер.: Філологія. - Випуск 29. - Том 1. - Одеса, 2017. - С. $74-76$.

\section{REFERENCES}

1. Ashytok, L. (2015). Komunikatyvna kompetentnist pedahoha: struktura, etapy formuvannia [The communicative competence of the teacher: structure, stages of formation]. Yoth \& market, no.6 (125), pp. 10 - 13. [in Ukrainian].

2. Vvedenskij, V.N. (2003). Kompetentnost pedagoga kak vazhnoe uslovie uspeshnosti ego professionalnoj deyatelnosti [The competence of the teacher as an important condition for the success of his professional activities]. The innovations in education, no.4, pp. 21 - 31. [in Russian].

3. Dehtiarova, N.V. (2017). Zastosuvannia ese z metoiu rozvytku komunikatyvnoi kompetentnosti maibutnikh uchyteliv informatyky [Application of essay in order to develop the communicative competence of future teachers of computer science]. Physical and mathematical education, vol.2(12), pp. $57-60$. [in Ukrainian].

4. Yeshchenko, Iu. F. (2010). Komunikatyvna kompetentnist yak skladova profesiinoi kompetentnosti vykladacha vyshchoho navchalnoho zakladu [Communicative competence as a component of professional competence of a teacher of a higher educational institution]. Bulletin of the National Academy of the State Border Guard Service of Ukraine, vol.2, Retrieved from http://nbuv.gov.ua/ UJRN/Vnadps_2010_2_11. [in Ukrainian].

5. Kasiarum, K. V. (2013). Komunikatyvna kompetentnist vykladacha vyshchoi shkoly [The communicative competence of the teacher of higher education]. The scientific treasury of education of Donetsk region, no.2(15), pp. 24 - 27. [in Ukrainian].

6. Kryvonos, O. M. (2013). Formuvannia informatsiino-komunikatsiinykh kompetentnostei maibutnikh uchyteliv informatyky $\mathrm{v}$ protsesi navchannia prohramuvannia [Formation of information and communication competences of future teachers of informatics in the process of programming of programming]. Candidate's thesis. Kyiv, 284 p. [in Ukrainian].

7. Kubenko, I. M. (2010). Shcho take kompetentnist i yak yii rozumiiut $\mathrm{v}$ osviti [What is competence and how it is understood in education]. Appendix to the journal "Theory and Methods of Education Management", vol. 1, Retrieved from http://www.tme.umo.edu.ua/docs/Dod/1_2010/ kubenko.pdf. [in Ukrainian].

8. Ovarchuk, O. (2007). Kompetentnosti, yak kliuch do onovlennia zmistu osvity [Competence as a key to updating the content of education]. Retrieved from http://osvita.ua/school/method/381/. [in Ukrainian].

9. Samborska, N.M. (2016). Komunikatyvna kompetentnist u strukturi profesiinoi kompetentnosti maibutnoho fakhivtsia [Communicative competence in the structure of professional competence of a future specialist]. Bulletin of Zhytomyr Ivan Franko State 


\section{СИСТЕМНИЙПДХІДУ ДОСЛДЖЕННІСИСТЕМИ РОЗВИТКУ ТВОРЧОГО ПОТЕНЦАЛУ IНЖЕНЕРІВ АГРАРНОЇСФЕРИ}

University. Pedagogical sciences, vol.1, pp. $126-$ 130. [in Ukrainian].

10. Ukaz Prezydenta Ukrainy Pro Natsionalnu stratehiiu rozvytku osvityv Ukraini na period do 2021 roku vid 25 chervnia 2013 roku № 344/2013 [Decree of the President of Ukraine On the National Strategy for the Development of Education in Ukraine for the period up to 2021; 25.06.2013 № 344/2013]. Retrieved from http://zakon3.rada.gov.ua/laws/show/344/2013. [in Ukrainian].

11. Cherezova, I.O. (2014). Komunikatyvna kompetentnist yak intehralna yakist osobystosti [Communicative competence as integral quality of personality]. Scientific Herald of Kherson State University, vol.1(1), pp. 103 - 107. [in Ukrainian].

12. Sharova, T.M. (2017). Istoriia ukrainskoi literatury I pol. XIX st. [The history of Ukrainian literature of the first part of the nineteenth century]. Kharkiv: Maidan, 272 p. [in Ukrainian].

13. Sharova, T.M., Sharov, S.V., \& Borodykhina, O.V. (2017). Formuvannia komunikatyvno-dialohichnoi kompetentnosti studentiv-filolohiv [Formation of communicative-dialogic competence of studentsphilologists]. Scientific Herald of the International Humanitarian University. Series: Philology, vol.29(1), pp. 74 - 76. [in Ukrainian].

Стаття надійшла до редакції 10.07.2018

УДК 378.147

DOI:

Олена Тітова, кандидат педагогічних наук, докторант кафедри педагогіки і педагогічної майстерності

Мелітопольського державного педагогічного університету імені Богдана Хмельницького

\section{СИСТЕМНИЙ ПІДХІД У ДОСЛІДЖЕННІ СИСТЕМИ РОЗВИТКУ ТВОРЧОГО ПОТЕНЦІАЛУ ІНЖЕНЕРІВ АГРАРНОЇ СФЕРИ}

У статті подаються результати застосування системного підходу у дослідженні системи розвитку творчого потенціалу майбутніх інженерів для аграрного виробництвв. Проаналізовано педагогічну систему підготовки творчого інженера у аграрних університетах. Визначено методологічні принципи для забезпечення системної спрямованості дослідження. Результати системного аналізу проблеми склали основу для розроблення та обтрунтування теоретико-методологічних засад розвитку творчого потенціалу майбутнього агроінженера.

Ключові слова: творчий потенщіал інженера; інноваційна інженерна діяльність; системний підхід; підготовка агроінженерів; розвиток інженерної творчості.

Jim. 12.

Olena Titova, Ph.D.(Pedagogy), Doctoral Student of the Pedagogy and Pedagogical Skills Department Melitopol Bohdan Khmelnytskiy State Pedagogical University

\section{APPLICATION OFTHE SYSTEM APPROACHTO STUDY THE SYSTEM FOR DEVELOPMENT OF THE AGRICULTURAL ENGINEER'S CREATIVE POTENTIAL}

In the current research, the development of creative potential among the engineering students involved the substantiation and introduction of a pedagogical system into the educational process of agrarian universities. It enabled to realize the purposeful formation of the engineer's creative potential through the transformation of all the components of the process (goals; content of education; forms, methods, means; diagnosis of the students' academic achievements; the teaching and learning activities). That could bring the gradual mastery of the student's innovation engineering.

The pedagogical process of an agrarian university was considered as a system, which combined the interacting elements, so that they existed as a whole. The system approach allowed identifying the primary and secondary elements, as well as the weak elements. It was also possible to determine the limitation of the weakest element and establish the ultimate goal of the system transformation.

The system approach enabled the definition of conditions for the successful realization of the ultimate goal, the identification of ways to implement it, the selection of the necessary forms, methods and means and their adaptation to the existing conditions and predicted goals.

To ensure the systematic orientation of the study within the system approach, a number of methodological principles have been analyzed and applied: the principle of integrity, the principles of predominance and hierarchy, the principle of structuring, the principle of self-organization and the principle of connection with the environment.

Since modern mechanisms for the effective management of the pedagogical system are based on the principles

(C) О. Тітова, 2018 